Revue musicale OICRM

\title{
Towards an Embodied Understanding of Performing Practices. A Gestural Analysis of Debussy's “Minstrels” According to the 1912 Piano Rolls
}

\author{
Jocelyn Ho
}

Volume 2, numéro 1, 2014

La réception de Debussy au XXe siècle. Incidences, influences et autorité

URI : https://id.erudit.org/iderudit/1055845ar

DOI : https://doi.org/10.7202/1055845ar

Aller au sommaire du numéro

Éditeur(s)

OICRM

ISSN

2368-7061 (numérique)

Découvrir la revue

Citer cet article

Ho, J. (2014). Towards an Embodied Understanding of Performing Practices. A Gestural Analysis of Debussy's “Minstrels” According to the 1912 Piano Rolls. Revue musicale OICRM, 2(1), 40-58. https://doi.org/10.7202/1055845ar

\section{Résumé de l'article}

La performance sur piano mécanique que propose Debussy en 1912 du prélude " Minstrels " (issu du premier livre des Préludes), contient des techniques expressives qu'on entend très peu dans les enregistrements contemporains : des tempos et des attaques plus relâchés, des altérations rythmiques jouées de manière désinvolte, des parties dans un style inégal et des tempo rubato. Bien que ces techniques puissent apparaître étranges aujourd'hui, elles étaient communes au tournant du siècle. Cette vivifiante exécution du prélude, qui révèle des techniques absentes de la partition, altère de manière significative notre expérience musicale. Des significations inédites qui ne sont pas repérables dans l'étude de la partition émergent une fois que l'on tient compte de l'interprétation proposée par Debussy. Cet article propose une approche qui montre l'importance égale de la partition et de la performance de Debussy dans la poursuite d'une analyse structurelle. Le concept de geste est utile dans la mesure où il peut être construit à la fois comme une assise dans la partition et une approche performative ou physique. De plus, dans " Minstrels ", un geste physique propre à une autre dimension existe par l'allusion au spectacle de ménestrel (i.e. blackface minstrel show). Dans l'analyse, les concepts basés sur le corps en lien avec le spectacle de ménestrel servent à décrire les gestes et leurs transformations. Dans une perspective merleau-pontienne, l'analyse traite ainsi le geste à la fois comme quelque chose de musical et de physique, s'éloignant ainsi de l'approche cognitive plus traditionnelle. Au final, l'étude démontre la présence de deux processus structuraux au sein du prélude : celui de la désorientation et celui de l'ascendance vers le haut (i.e. upward reaching). Ces deux processus culminent dans la section expressive mais sont freinés par un geste d'incohérence dans l'interprétation du prélude. Une lecture historique qui tient compte du corps masculin noir dans le contexte du spectacle de ménestrel révèle que le geste qui structure le prélude comprend aussi des significations sociohistoriques. La convergence entre l'étude historique de la performance musicale et l'analyse gestuelle du corps permet un investissement important dans la structure, le travail compositionnel et les significations culturelles propres à la musique de Debussy.
Ce document est protégé par la loi sur le droit d'auteur. L’utilisation des services d'Érudit (y compris la reproduction) est assujettie à sa politique d'utilisation que vous pouvez consulter en ligne.

https://apropos.erudit.org/fr/usagers/politique-dutilisation/ 


\title{
Towards an Embodied Understanding of Performing Practices. A Gestural Analysis of Debussy's "Minstrels" According to the 1912 Piano Rolls
}

\author{
Jocelyn Ho
}

\begin{abstract}
Résumé
La performance sur piano mécanique que propose Debussy en 1912 du prélude « Minstrels» (issu du premier livre des Préludes), contient des techniques expressives qu'on entend très peu dans les enregistrements contemporains : des tempos et des attaques plus relâchés, des altérations rythmiques jouées de manière désinvolte, des parties dans un style inégal et des tempo rubato. Bien que ces techniques puissent apparaître étranges aujourd'hui, elles étaient communes au tournant du siècle. Cette vivifiante exécution du prélude, qui révèle des techniques absentes de la partition, altère de manière significative notre expérience musicale. Des significations inédites qui ne sont pas repérables dans l'étude de la partition émergent une fois que l'on tient compte de l'interprétation proposée par Debussy. Cet article propose une approche qui montre l'importance égale de la partition et de la performance de Debussy dans la poursuite d'une analyse structurelle. Le concept de geste est utile dans la mesure où il peut être construit à la fois comme une assise dans la partition et une approche performative ou physique. De plus, dans « Minstrels », un geste physique propre à une autre dimension existe par l'allusion au spectacle de ménestrel (i.e. blackface minstrel show). Dans l'analyse, les concepts basés sur le corps en lien avec le spectacle de ménestrel servent à décrire les gestes et leurs transformations. Dans une perspective merleau-pontienne, l'analyse traite ainsi le geste à la fois comme quelque chose de musical et de physique, s'éloignant ainsi de l'approche cognitive plus traditionnelle. $\mathrm{Au}$ final, l'étude démontre la présence de deux processus structuraux au sein du prélude : celui de la désorientation et celui de l'ascendance vers le haut (i.e. upward reaching). Ces deux processus culminent dans la section expressive mais sont freinés par un geste d'incohérence dans l'interprétation du prélude. Une lecture historique qui tient compte du corps masculin noir dans le contexte du spectacle de ménestrel révèle que le geste qui structure le prélude comprend aussi des significations sociohistoriques. La convergence entre l'étude historique de la performance musicale et l'analyse gestuelle du corps permet un investissement important dans la structure, le travail compositionnel et les significations culturelles propres à la musique de Debussy.
\end{abstract}

Mots clés : analyse gestuelle ; analyse de performance ; Debussy ; ménestrel ; piano mécanique. 


\begin{abstract}
Claude Debussy's performance of "Minstrels" from Preludes, Book I, in the 1912 piano rolls contains expressive techniques that are not often heard today: random pushes and pulls of tempi, flippant rhythmic alterations, frequent inégale, and tempo rubato. These performing practices, although odd-sounding to the modern listener, were common at the turn of the twentieth century. His vivid rendition of the piece, including these expressive techniques that are missing from the notation, significantly alters the experience of the music. Unexpected meanings that cannot be deduced from studying the score alone arise when taking into consideration Debussy's interpretation as a performer. This article gives an integrative analysis that regards the score and Debussy's performance as equally important in a structural analysis. The concept of gesture is useful here, as it can be construed in both a score-based and a performative or physical approach. Moreover, in "Minstrels," an extra dimension of physical gesture exists in its allusion to the blackface minstrel show. In the analysis, active, bodily-based concepts drawn from the blackface minstrel show are used to describe gestures and their transformations. From a Merleau-Pontyian perspective, the analysis thus treats gesture as at once musical and physical, moving away from a traditional, cognitive-based approach. The analysis shows the emergence of two large-scale structural processes-that of disorientation and that of upward reaching. These two processes culminate in the expressif section but are undercut by a dominating gesture of incoherence. A closer historical reading of the ridiculed, male "black" body in the context of blackface minstrelsy reveals that the emergent gesture-based structure of the piece can afford socio-historical meanings. The convergence between the study of historical performing practices and embodied gestural analysis yields fresh, important insights into the structure, inner workings and cultural significances of Debussy's music.
\end{abstract}

Keywords: blackface minstrelsy; Debussy; gestural analysis; performance analysis; piano rolls.

Claude Debussy's Welte-Mignon piano rolls of 1912 reveal that (Debussy 1912), as a pianist, he firmly upheld late-Romantic performing traditions. His playing as heard in the rolls produced imaginative effects and characterizations that reflect the practices of his time. Much analysis has been done on these piano rolls with the aim of revealing his practices and for editorial purposes; as a reference point, the Durand-Costellat edition of Debussy's complete piano works by Roy Howat (Debussy 1985-2002) contains valuable comparative insights between the score and the piano rolls. Richard Langham-Smith's "Debussy on Performance. Sound and Unsound Ideals" (1999) and Charles Timbrell's "Debussy in Performance" (2003) are among the various literature that deal with understanding the performing practices of Debussy and his contemporaries. And my paper, "Debussy and Late-Romantic Performing Practices. An Investigation of the Piano Rolls of 1912" (2012), contains a cross-sectional analysis of the piano rolls showing his use of late-Romantic practices that are seldom used today. ${ }^{1}$

1 In this paper, I have also made a case for the piano rolls' credibility as evidence of Debussy's playing. According to experts in the field of reproducing pianos, note placements and relative tempi within a roll are completely reliable. Thus, dislocation of the hands, unnotated arpeggiations, tempo modification, and rhythmic alteration are dependable areas of performing practices on which musical analysis could be based. 
An interesting and potentially fruitful progression of this research would be to analyze his performing practices in relation to musical structure and meaning.

In "Debussy and Late-Romantic Performing Practices," I have discussed instances when his performing practices contribute to musical meaning, for instance, in "Golliwogg's Cake-walk" and "Minstrels." In these two pieces, the ubiquitous application of a jagged type of rhythmic alteration creates a parodying and strong impression of blackface Minstrelsy show, which is in stark opposition to the smooth tempo modifications of the waltz in "La plus que lente." The topical opposition of "the ridiculous" versus "the serious" exists not only on the level of performing practices, but resonates at the level of cultural meaning, as the cake-walk is originally a mockery of European dances by black people (Hitchcock and Norton 2009). At other times, new meanings that contradict those deduced from the score are produced by Debussy's performance, for instance, in "Gradus ad Parnassum," where the clear use of inégale and rhythmic dotting points towards an ironic mockery of Muzio Clementi's technical exercises. From the various examples where performing practices are active participants in forging musical meaning, it is clear that the score alone is inadequate as the basis of a musical analysis. This points to an integration of the performance and the score as a necessary basis for analysis.

Indeed, in the field of performance analysis, the notion of a musical 'work' has warranted much discussion. The concept of "the work itself" that upholds the score as sacrosanct, while relegating the specificities of performances as subordinate, has been under increasing scrutiny. Instead, Nicholas Cook advocates the idea of a work as "something existing in the relation between its notation and the field of its performances," where "the different modes of a work's existence" (Cook 2003, p. 206-207) include both the score and different performances. This more inclusive approach that regards the score and performance as equally important takes into account the multitude of interpretative possibilities that written notation can afford. From this standpoint, the analysis of a work cannot be separated from its performances; practically speaking, even the scholar who theorizes about a piece of music without referring to specific performances cannot totally dissociate herself from the recordings to which she listens. Even without directly addressing performative issues in analysis, she cannot evade the context of common performing practices in which she is embedded. The traditional convention of regarding the analysis of a work as that which ignores the specificities of the performance thus comes into question, and it is incomplete and limited. With this in mind, I propose that taking into account Debussy's performing style when analyzing the pieces in the 1912 piano rolls results in deeper, new insights into the structure and inner workings of the compositions. Since the recordings are of the composer-pianist who plays his own music, the analysis could reveal meanings and possible compositional intentions that are only brought out in the recordings. This paper aims to give an example of such an integrative analysis in "Minstrels."

\section{Gesture: The Intersection of Music And Body}

A musical analysis that combines performance and score must necessarily be done in a context that addresses both as equals, and the concept of gestures is a 
useful and sufficient commonality between them. This is because a gesture can be understood in the context of both the musical (traditionally score-based) and the performative gestures at once. George Fisher and Judith Lochhead, in "Analyzing from the Body," distinguish between these two facets: while the musical gesture is a "sonically oriented concept" that combines features of pitch, rhythm, dynamics, texture, and so on to form a discrete, unified "event," the performative gesture is understood in the physical "execution," (Fisher and Lochhead 2002, p. 44) such as in one sweeping motion of the arm, or one exhalation of air. In analysis that takes into account the performance, these two aspects of gestures, the sonic and the bodily, are unified. Debussy's performance contains characterizations that highlight the musical gestures; thus, the performative gesture consolidates the understanding of the musical gesture, and the musical gesture only comes to life in the performance.

A gestural analysis that takes into account the physicality of performance is particularly suitable in the case of "Minstrels," which alludes to the American minstrel show (Schmitz 1950, p. 160). From the 1840s to the turn of the century, the imported American blackface minstrel show was in vogue in Europe; in fact, it was the single most popular form of American stage entertainment (Blair 1996, p. 3). Although there is no direct evidence, it is most likely that Debussy had experienced a minstrel show due to its popularity in Paris (McKinley 1986, p. 253). Needless to say, the blackface minstrel show, in which white men in blackface originally imitated black men, is a derisive racial parody. But what is significant is that the form of parody is very much a physical one, in which black people's manners, mores, dance, and music are being made fun of through ridiculous movements and contortions of the body. According to John G. Blair, it was the very physicality of the show that appealed to the European audience; the exaggerated movements resonated with their pre-existing concepts of primitivism in the New World (Blair 1986, p. 3-11). Various descriptions of the minstrel's dance, such as Thomas D. Rice's original "Jim Crow," have a bodily focus. While musicologist Dale Cockrell explained the dance as "an extraordinary moment of elevation in which his body kind of exploded off the stage, turned around, wheeled around and jumped Jim Crow," (Cockrell 2013) Hans Nathan describes it in detail:

Rice, according to his own words, wheeled, turned, and jumped. In windmill fashion, he rolled his body lazily from one side to the other, throwing his weight alternately on the heel of one foot and on the toes of the other. Gradually, he must have turned away from his audience, and on the words "jis so," jumped high up and back into his initial position (Nathan 1977, 52).

The significance of the body in blackface minstrelsy suggests that Debussy's "Minstrels," other than the performative gesture of the pianist, has an extra dimension of physicality attached to it - that of the bodily acts in the minstrel show. It is this physicality of exaggerated gesture, the blackface minstrel's body in awkward, "jumping," and "wheeling" action, that is heard vividly in Debussy's performance of "Minstrels." Historically speaking, various images of humorous bodily acts such as "tumbling" and "tap dancing" have been used by pianists and musicologists to portray the work (McKinley 1986, p. 254-256). Debussy's performing practices of 
dislocation of hands, tempo modification, and rhythmic alterations draw particular attention to the gestural composition of events that can be compared with these physical, bodily gestures found in a minstrel show. for instance, a consistently rushed, three-note, ascending figure becomes a lunging forward action, the use of inégale to play alternating chords emerges as a wobbling gesture, and the rhythmic dotting and uneven rendition of a quickly descending flight of notes is heard as a clumsy tumbling down. Thus, the musical and performative gestures of Debussy noticeably merge with the bodily gestures of lunging, wobbling, tumbling, and so on, as in a minstrel show.

\section{LOCATING THE Gesture IN THE Body}

In understanding the structure of the piece by integrating Debussy's performing practices, then, a non-traditional analysis that is gesture-oriented emerges, where "gesture" is construed as the intersection of the musical and the bodily (pertaining to both the performative and the alluded imagery of the minstrels show). Such an analysis based on gesture that is at once musical and physical derives from the Merleau-Pontyian concept that regards the body, rather than merely the disembodied mind, as central to how humans understand the world. ${ }^{2}$ Through explicit or implicit bodily actions, and not only cognitive activity, meaning is created. In addition to rejecting the Cartesian mind-body split, Merleau-Ponty also purports that the way in which our body experiences the world is not divided into sensory components such as sight, touch hearing, and so on. Rather, a "thing" is experienced as an "inter-sensory entity," where all our senses communicate with one another. In Phenomenology of Perception (1962), Merleau-Ponty writes (emphasis mine):

And in so far as my hand knows hardness and softness, and my gaze knows the moon's light, it is as a certain way of linking up with the phenomenon and communicating with it. Hardness and softness, roughness and smoothness, moonlight and sunlight, present themselves in our recollection, not preeminently as sensory contents but as a certain kinds of symbiosis, certain ways the outside has of invading us and certain ways we have of meeting this invasion, and memory here merely frees the framework of the perception from the place where it originates (the quote is taken from Merleau-Ponty 1999, p. 166).

Thus, according to Merleau-Ponty, in experiencing music, we are not merely hearing it with our auditory component. Instead, for instance, we are also feeling the thick texture of a fully orchestrated chord, sensing the highs and lows of a pitch range, seeing the bright tone colour of the flute, or soaking up the warmth of the chalumeau register of a clarinet. The language with which we speak of music already points

2 Maurice Merleau-Ponty, regarded as the founder of embodiment philosophy, sees the bodily experience as the starting point of human knowledge and understanding. Meaning and significance comes from an individual's embodied being in the world, and the intersubjective sharing of cultural frameworks. In music, then, musical meaning arises out of our bodily performances, capabilities and potentialities and our shared understanding of what these bodily experiences signify. 
towards this inter-sensory experience. This experience is not merely metaphorical, but real in the way our memories of height, temperature, sight, and touch, become enmeshed in a "symbiosis" as a fully corporeal experience. And so, in Debussy's "Minstrels," our bodily knowledge of the speeds, forces, directionalities, lightness and heaviness associated with lunging, wobbling and tumbling down, and our bodily resonances with a minstrel that we have perhaps watched or imagined inform us on our inter-sensory understanding of the musical gestures in the piece. In this way, musical gestures are a bodily experience, drawing on our bodily knowledge of the world in imaginative possibilities. Scholars have done much to highlight the musical gesture as embodied: David Lidov in "Mind and Body in Music" identifies "musical" and "muscular gestures" (Lidov 1987, p. 77-78) as coming from the same origin, while Arnie Cox , along the same vein, describes musical gestures as "musical acts" (Cox 2006, p. 45) in "Hearing, Feeling, Grasping Gestures." 3 These ideas resonate with Fisher and Lochhead's proposal for a kind of practical, gestural analysis that promotes the understanding of music in terms of the "explicit or implicit movements of the physical body" (Fisher and Lochhead 2002, p. 39). This study responds to their call by breaking down the barrier between the score and the performance and embracing its bodily component.

Naturally, this kind of analysis does not have an established method that prescribes how the body relates to the musical score; only the consideration of the physical demands and skillsets of different instrumentalists points towards a phenomenological, non-prescriptive type of analysis that investigates each piece with a fresh start. In "Analyzing from the Body," two very different methods have been used for Joan Tower's Fantasy (Those Harbor Lights) and Johannes Brahms's Sonata for Clarinet and Piano in E flat, op. 120, $\mathrm{n}^{\circ}$ 2, Third movement (ibid., p. 50-61). While the former uses general, visceral sensations of "rising," "rocking," and "upward resolution" as the basis of analysis, the latter focuses on the specific actions of the pianist and clarinettist's arms, torso and fingers. In "Minstrels," the bodily focus must at once address the body in performance as well as the alluded bodily acts of a minstrel. Here, I draw on Arnie Cox's research into the location of where a listener "comprehends" a musical passage in "Hearing, Feeling, Grasping Gestures." According to Cox, one can comprehend a violin passage at different levels: through "imitation of the fingers and bowing," through "subvocal imitation of the musical sounds produced," and through an "amodal, visceral imitation of the exertion dynamic of the event" (Cox 2006, p. 52). Consequently, although performers and listeners of different backgrounds may have different bodily toolsets, they still share an intersubjective, visceral, or "amodal" response to music.

The "amodal" sensation exhibits itself specifically, for instance, in the clarinettist's embouchure control as well as a listener's torso. In "Minstrels," while alternating chords played with inégale could be felt as an unsteady wobbling to and fro in the

3 Lidov's article was a prompt for Arnie Cox's elaboration of various modes of musical responses based on the idea of mirror neurons. 
torso and the arms of the performer, the visceral feeling of this wobble is the basis for a wobbling in the listener's imagined dancer's legs. Likewise, the dotting and uneven rendition of a quickly descending flight of notes is physically enacted through a non-uniform action of the fingers that hesitate and trip, in conjunction with the arm that follows an arc going to the left. The "amodal," visceral feeling of this gesture is the basis for an imagined clumsy tumble of a minstrel. In this study, I will be drawing from active, bodily-based concepts to describe gestures and their transformations. These gestures draw on both the explicit physical movements of the performer and the imagined possibilities of a minstrel, the "amodal" sensation being a common basis for both. The embodied gestures serve as the starting point for a structural analysis of the piece. Both the score and exact timings from the accompanying recording of the piano roll will be referred to during the analysis. ${ }^{4}$

Musical example 1: Claude Debussy, Preludes, Book I, no 12, "Minstrels," Claude Debussy (rec. 1912), transfer by Denis Hall, CD, 2012. Écouter.

\section{The ANALYsis}

"Minstrels" is in a ternary form with a coda, in which the middle section is extended in length. Here is an outline of the piece with a summary of the overarching processes:

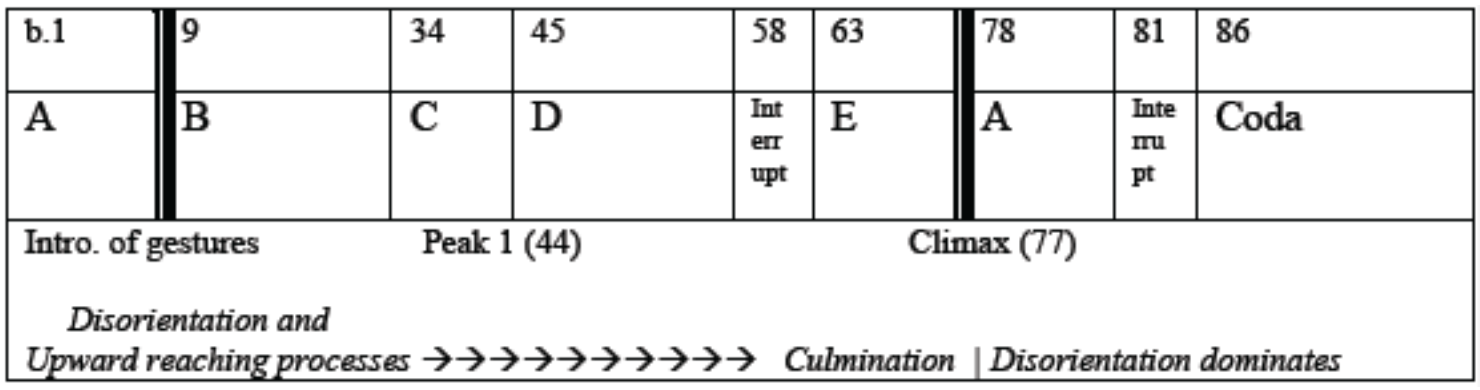

Figure 1: Formal outline of "Minstrels" and summary of processes.

A general sense of destabilization is established in sections A and B through Debussy's different rhythmic executions of five gestures. Two large-scale processes that lead to the climax (bar 77) occur simultaneously throughout the piece, that of disorientation and that of an upward, directional reaching. These two processes come together and culminate in section $\mathrm{E}$, the expressif section, ending with the climax. The return of $\mathrm{A}$ and the coda sees the dominant process of disorientation finishing the piece. Debussy's performing practices of rhythmic alteration, tempo modification, and dislocation of the hands in conjunction with musical details found in the score drive these processes and forge the structural details that constitute them.

A general, destabilizing sense of rhythm is established in the beginning with two alternating gestures (musical example 1, 0'-0'12'): a three-note, ascending,

4 Transcriptions of performing practices in this study are based on Denis Hall's unpublished transfer of the roll. Many thanks to Denis for supplying the recording that accompanies this study. 
lunging forward gesture (bar 1) played with an unmarked accelerando (boxed in red and marked by a forward arrow), which is cut off by a brute, unsubtle V-I stomp gesture (blue, bars 1-2). These two gestures are delineated from each other by the unmarked, lengthened silences between them (marked by a backward arrow) and the dislocation of the hands in bar 2 and 6, creating a choppy, discontinuous feeling. The sense of destabilization is reinforced in section $\mathrm{B}$, where three distinct gestures in quick successions are played with different rhythmic alterations (musical example 1, 0'12'-0'21'): a steady teeter-totter gesture (green, bars 9-10), a clumsy, tumbling down gesture (purple, bars 11-12) achieved through inégale, and a wobble gesture (yellow, bars 14-16), the latter consisting of off-kilter, alternating chords played slightly unevenly. ${ }^{5}$ The different rhythmic alterations that Debussy as pianist executes forefront the physical differences of the three gestures, and a sense of disorientation is achieved through their unpredictable renditions in a short time span of merely seven bars. These five gestures form the basis of the piece.

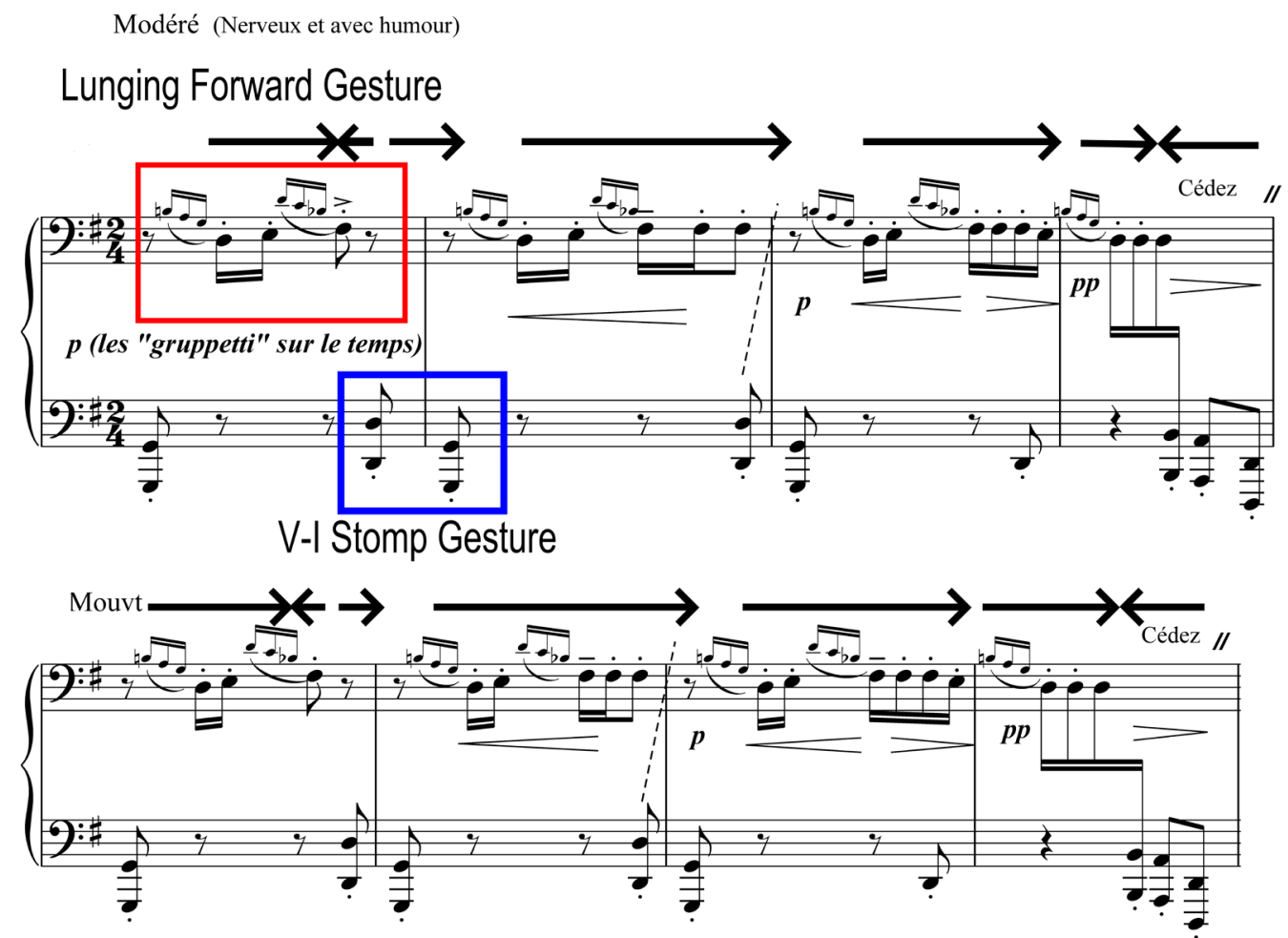

Figure 2: "Minstrels," bars 1-8, back arrow indicating a retardando, forward arrow indicating an accelerando, slant broken line indicating dislocation of hands as heard in the piano roll. 
Mouvt ( Un peu plus allant)

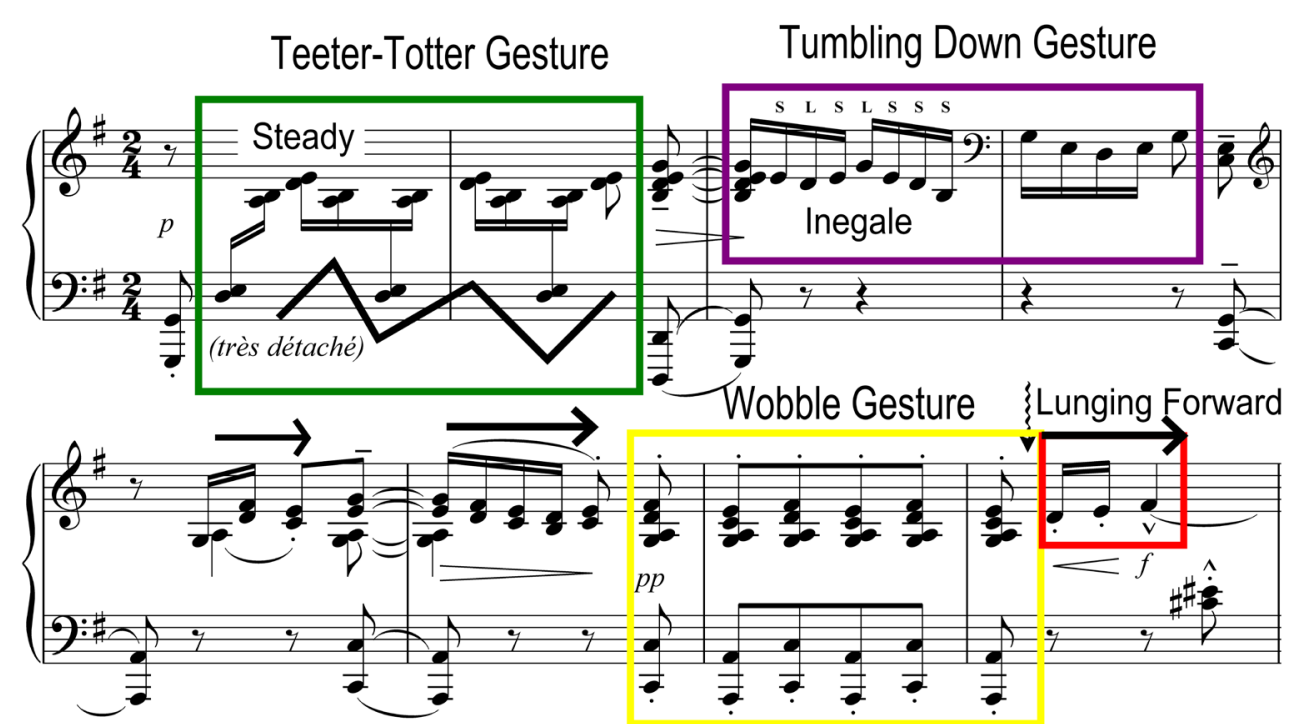

Figure 3: "Minstrels," bars 9-16. 'S' and 'L' mark the inégale and the downward squiggly arrow indicates an interruption achieved through the following, sudden accelerando.

At this point, I would like to note that the sense of disorientation, although seemingly obvious when considering the score alongside Debussy's performance, is not necessarily heard in other pianists' performances. For instance, in recordings by Arthur Rubinstein (Debussy 1999) and Arturo Benedetti Michelangeli (Debussy 1984), two pianists well-regarded for their interpretations of Debussy's music, the renditions are much more rounded, the tempi steadier, and as a consequence, there is more a sense of flow throughout the introduction. In both recordings, the individual gestures that are delineated through different rhythmic alterations of inégale, pushes and pulls of tempi and unevenness in bars 9-16 by Debussy are homogenized in a way that they become apprehended as one flowing passage. The impression of separate physical acts such as clumsy tumbling down or unsteady wobbling is thus absent or more abstracted in these recordings. Debussy's rendition of the beginning of the piece, in contrast, establishes the physicality of the gestures that create a sense of disruption and destabilization. ${ }^{6}$

\section{First Process of Disorientation}

After these beginning bars, a process of disorientation consisting of interruption, incoherence, and brief coherence undercut by incongruity governs the events from

6 While it is my intention to combine the score and Debussy's performance together in this analysis in light of Cook's vision of seeing the "work" as an amalgamation of both, it is important also to note that the conclusions drawn are unique to Debussy's performance. One cannot necessarily deduce the same conclusions from other pianists' recordings, or from the score alone. It is not my goal here to make a comparative analysis between the interpretations of Debussy and other pianists, but for the sake of pointing out the indispensability of Debussy's performance, I will refer to some other recordings along the way to highlight this point. 
section B towards the climax at bar 76. A map of this process of disorientation is shown in Figure 4. The map combines the traditional formal outline with icons that represent events in the processes. ${ }^{7}$ While the zig-zag arrows represent interruptions, the use of colours-blocking versus blending-illustrates incoherence in contrast to coherence.

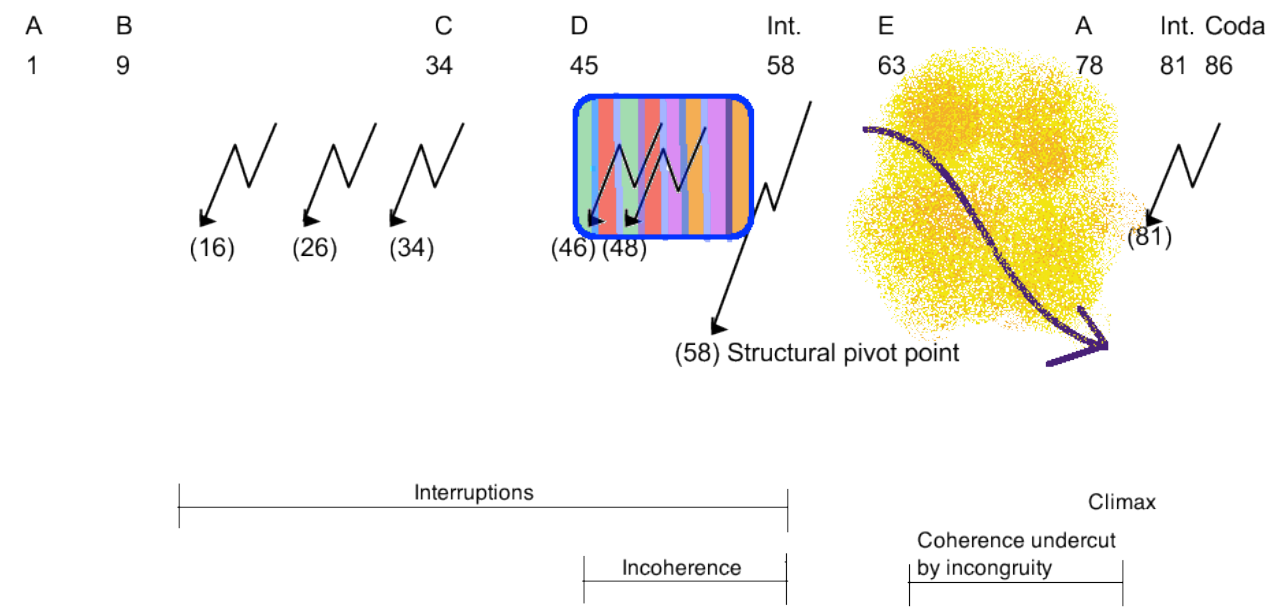

Figure 4: Map of process of disorientation.

The process of disorientation is achieved through the assumption of different functions by certain gestures: the lunging forward and the stomping gestures become interrupters in sections B and D respectively. In bars 16 and 26, the directional lunge forward that is accompanied by a quick crescendo to an $\mathrm{f}$ suddenly interrupts the non-directional, $p p$ wobble gestures (musical example 1, 0'20' and 5, 0'30'). Similarly, in bars 46 and 48, the stomping gesture of V-I in F\# major is heard as interrupting the teeter-totter gesture because of its sudden accelerando (musical example 1, 0'51'). These sudden, loud bursts that punctuate the texture contrast with the use of silence as an interrupter that doubly functions as a structural delineator at the end of section C (bar 33, musical example 1, 0'37'). The highly disruptive effect of this section is peculiar to Debussy's playing and not necessarily deduced from the score alone; the crescendo in bar 46 towards the stomp gesture could well imply a smooth lead-in to the forte dynamic, and the sforzando in bar 33 could proceed straight onto a subito piano. ${ }^{8}$ Debussy's use of interruption suddenly stops the flow of events and shifts the expectation of the listener without warning, creating a sense of momentary disorientation.

$7 \quad$ Such a non-traditional visual map that is free from the baggage of pre-conceived associations with other analytical methods is appropriate here for our phenomenological investigation.

8 In fact, this is the Michelangeli's interpretation, and the effect is much less disruptive and consequently, somewhat more polite. 


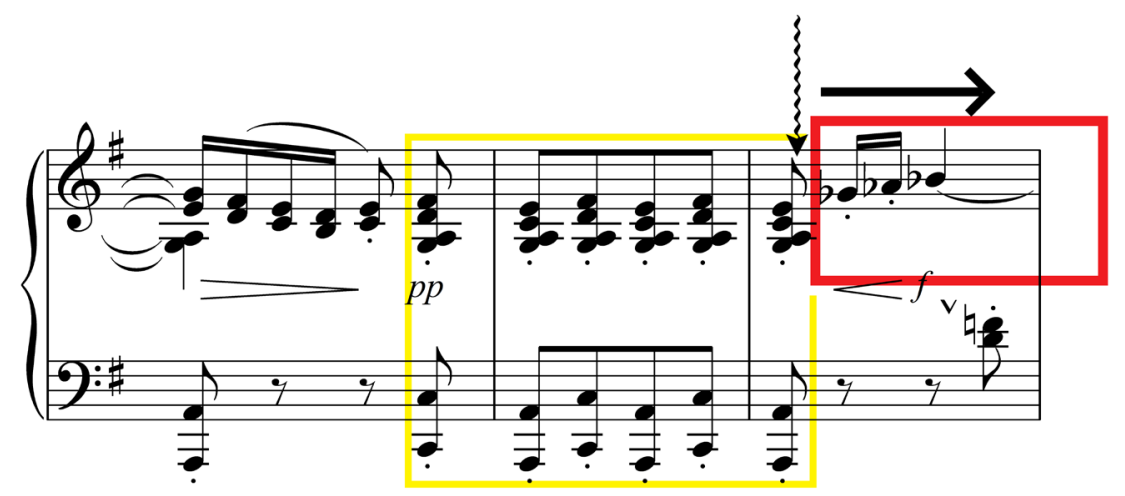

Figure 5: "Minstrels," bars 24-26, interruption marked by a squiggly arrow, unmarked accelerandi by a forward arrow.
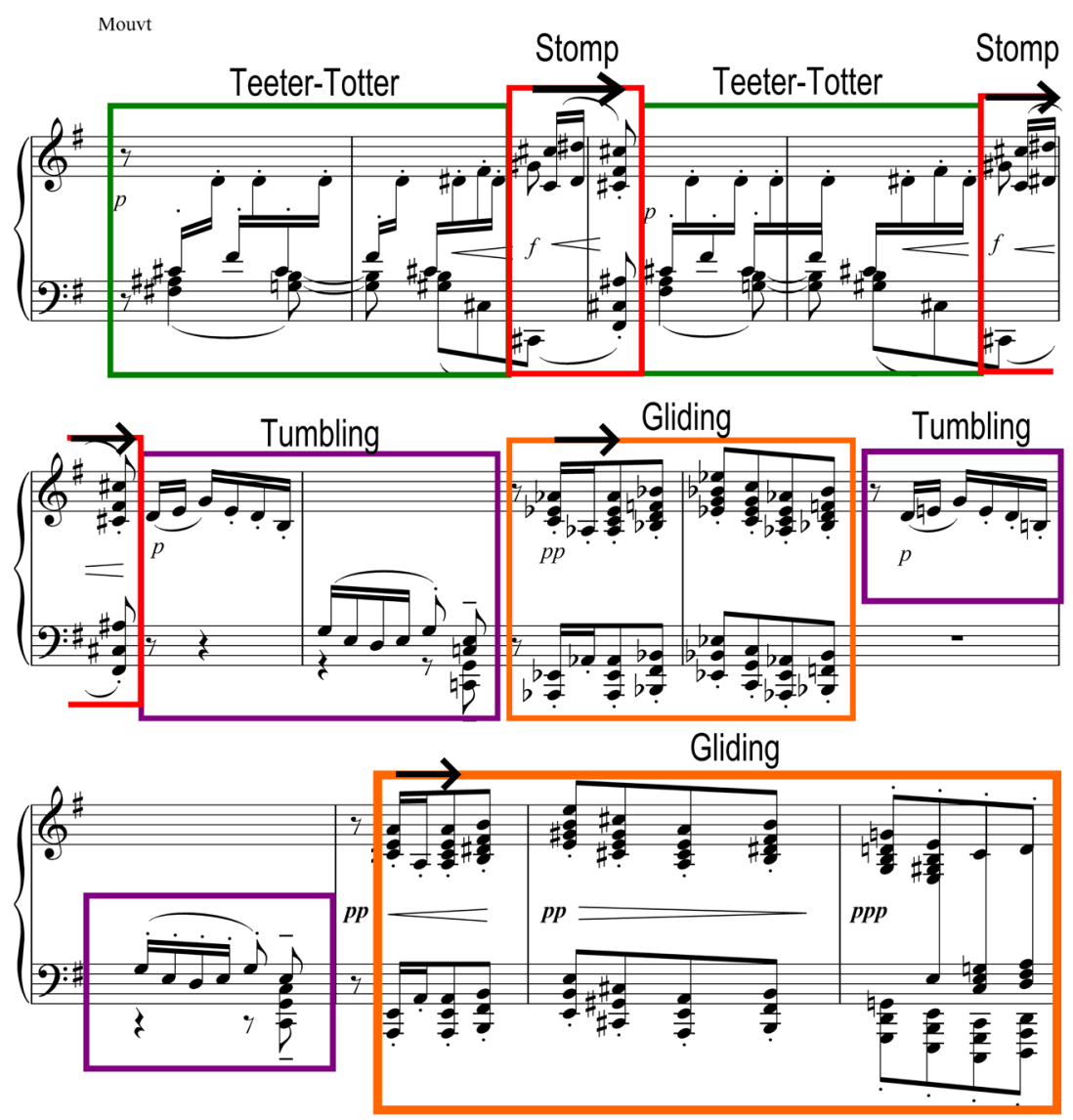

Figure 6: "Minstrels," bars 45-57, arrows indicate unmarked accelerandi, boxed figures indicate separate gestures as labeled. 


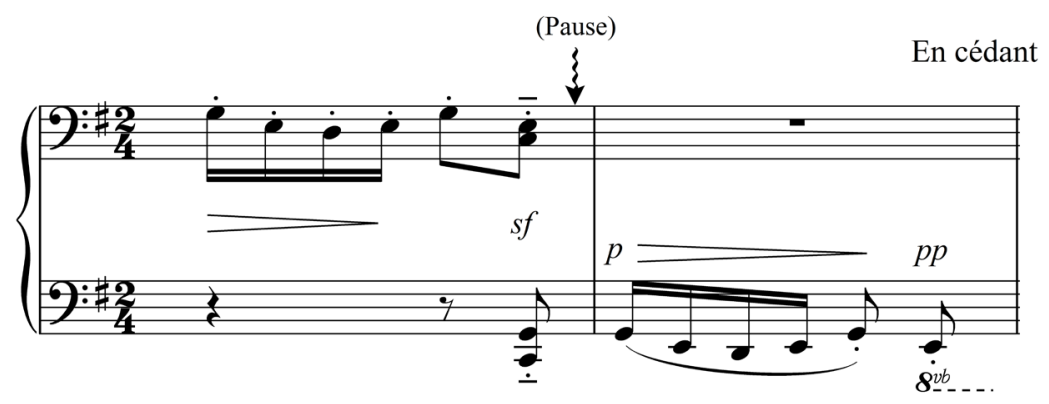

Figure 7: "Minstrels," bars 33-34, unmarked interruptive pause indicated by a squiggly arrow.

A more extended sense of disorientation happens in section D (bars 45-57) with the incoherent juxtaposition of different gestures (musical example 1, 0'50"). Here, a quick succession occurs, from the alternation of teetor-totter and stomp gestures, to that of the tumbling down gesture and a gliding, planing of chords. The dizzying, quick shifts of focus from one alternating action and texture to another in an unsteady, unpredictable surging of tempo that Debussy executes produce a kind of circular, dizzying, and babbling effect. This comical act of section D is then interrupted to give way to the furthest point of rhythmic alteration unmarked in the score: an isolated, repeated note that significantly accelerates then decelerates through six bars (bars 58-62, musical example 1, 1'03'), a lengthy duration compared to the short bursts of gestures heard up to this point.

The use of tempo rubato here by Debussy - the stealing and giving back of time-is structurally crucial. Although the gesture seems to be an intense focusing on to a single note from the preceding incoherent scattering, it is executed as dangerously unstable - the tempo modification seems to be an arbitrary push and pull without any reference point unlike previously. This lack of reference point in the use of unmarked accelerando and rallentando gives a sense of the whole body moving forward and backwards, unanchored in space. Thus, while section $\mathrm{D}$ is disorienting in its quick shifts of focus, this interruption focuses its scattered energy into a concentrated point of uncertainty and total, unanchored instability in a full-body participation of disorientation.

This physical gesture that incorporates the sense of the whole body cannot be deduced from the score; it is Debussy's use of tempo rubato that gives it its (particularly corporeal) gestural significance of full-bodied instability. Structurally speaking, this one repeated note of $\mathrm{D}$ that comes after a non-tonally-centered planing of chords serves as a pivotal moment that could lead anywhere, in terms of musical material, gesture and key. It is significant that the most unpredictable structural moment yet is executed with the most rhythmic instability, one that involves the whole body. In sharp contrast, a literal interpretation of the score, to play it "quasi tamburo" (like a drum), would result in a strict, smooth transition to the next passage; this full-bodied disorientation at a strong structural point would consequently not occur. After various interruptions of sounds and silence and incoherent utterances, we are thus left hanging on one unstable note, giddy and vertiginous. 

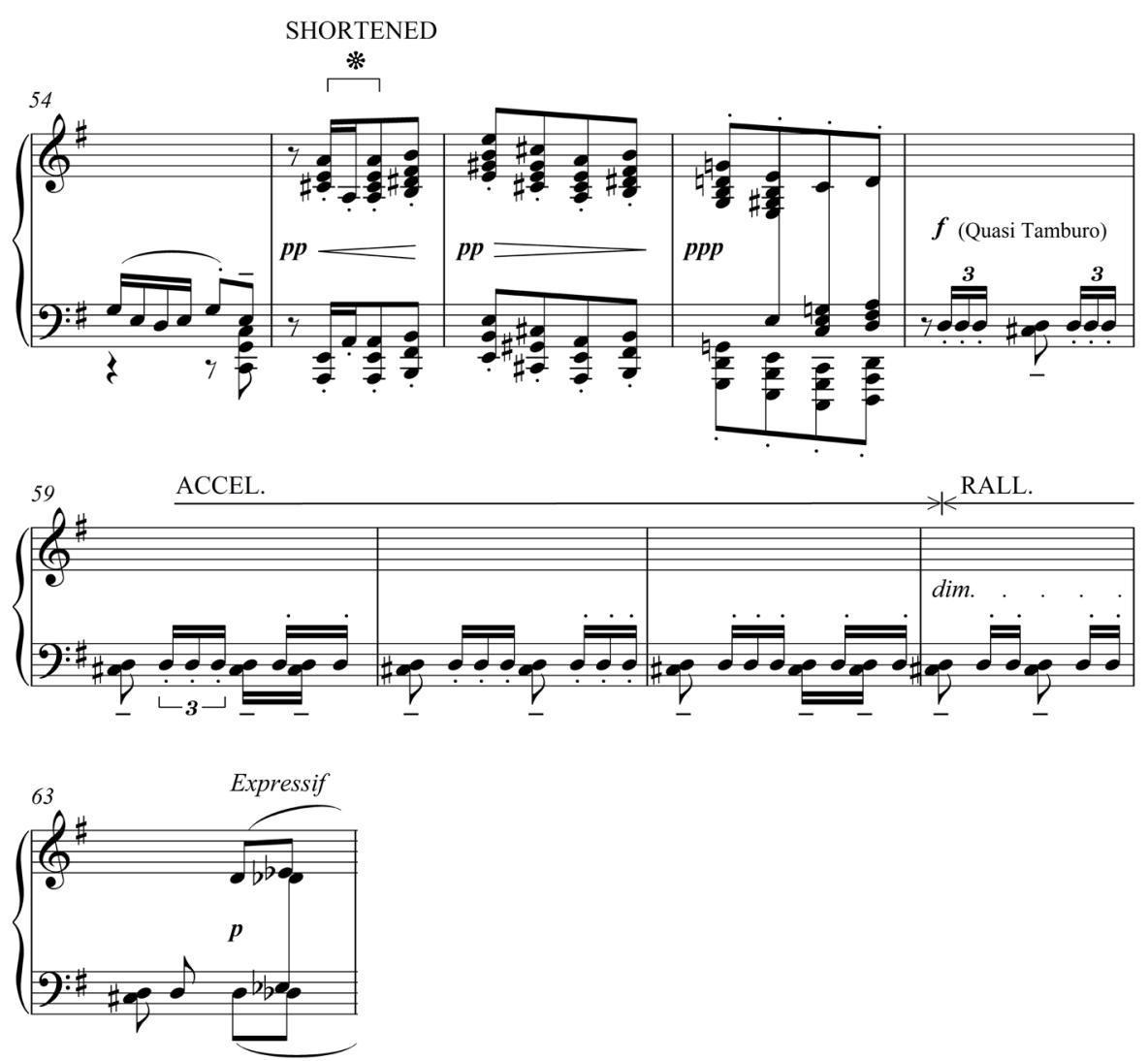

Figure 8: "Minstrels," bars 58-62, unmarked accelerando and rallentando indicated.

\section{Second Process of Upward Reaching}

Simultaneous with this process of disorientation is the three-stage process of upward reaching, as shown in Figure 9. In this map, the contours of the arrows illustrate the natures of the reaching up: limping, inching, and extending.

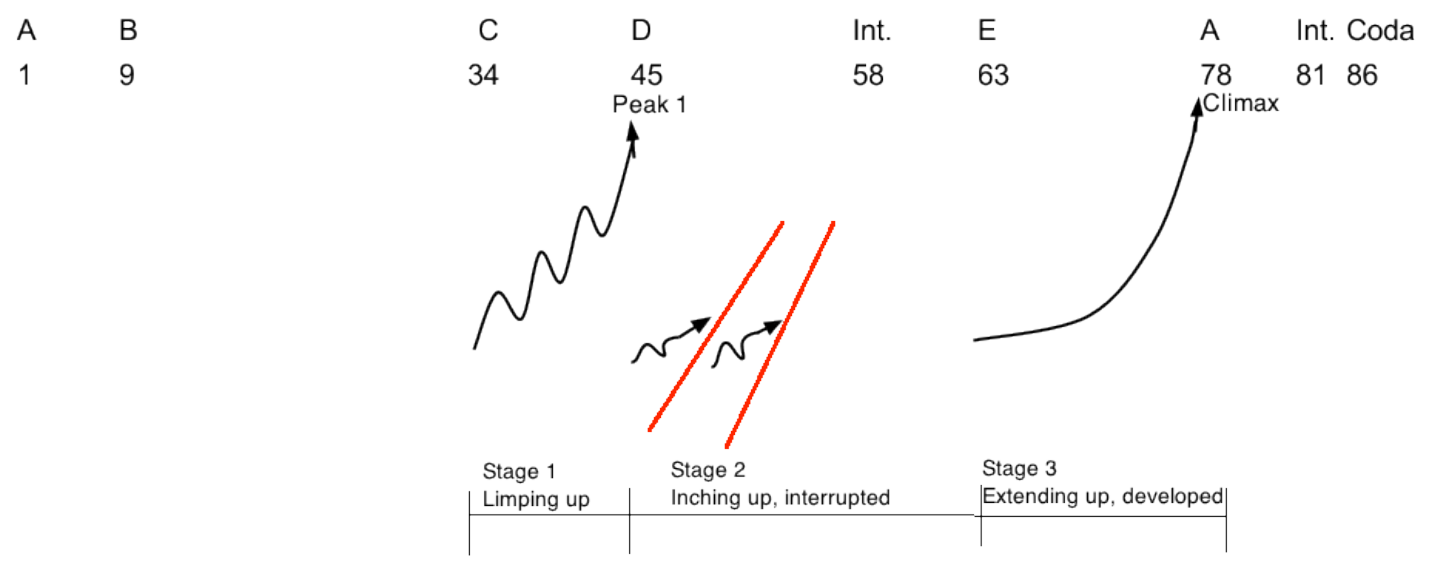

Figure 9: Map of process of upward reaching.

The first stage is a limping towards peak 1 in bar 44 , where gestures are transformed as awkwardly upward looking (musical example 1, 0'43'). The teeter-totter gesture (bars 39 and 41, boxed) is now a stuttering A-flat that spans three octaves, while the 
alternating left-hand octaves taken from the wobble gesture (bars 14-16, Figure 3) is a zig-zagging, upward, chromatic line from B-A-flat, to B-B-flat, to finally a C. The alternating half-diminished 9 th chords are adorned with chromatic grace notes, and although these could be construed as allusions to the banjo, they could also be heard as comical, clumsy crushes onto the main note. These chords are executed by Debussy with a limping rhythmic effect, where the B half-diminished 9ths are lengthened (bars 40 and 42) and the B-flat half-diminished 9th is shortened (bar 43), as shown by the markings of bold intervals and a forward arrow in Figure 10. This then ends with a sudden upward lunge towards a C-sharp in bar 44. Thus, the first stage of the upward process is a clumsy gathering together of gestures to form a wobbly, limping upwards reach towards a peak.

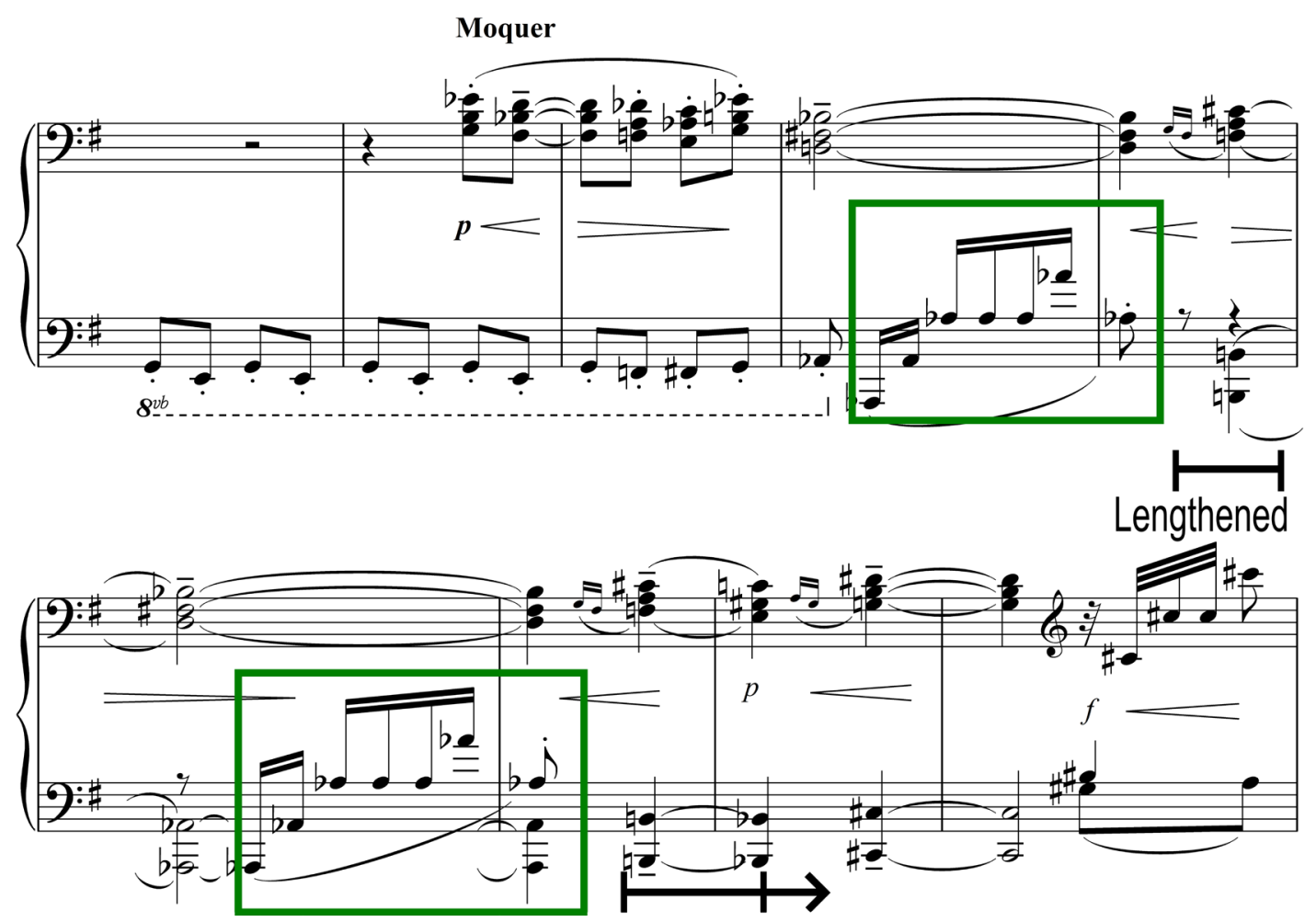

Figure 10: "Minstrels," bars 36-44.

The second stage (bars 45-49) in section D is a somewhat failed attempt at upwards reaching, where the teeter-totter gesture is accompanied by chromatic dyads in the left hand that inch slowly upwards (Figure 6, 0'50', boxed in green). This subtle creeping up is but comically trampled by the loud, brute, lunging V-I stomp gesture in bars 46 and 48, reinforced by Debussy's sudden rushing (marked by the forward arrow). ${ }^{9}$ The slow, chromatic creeping up can be construed as an effortful attempt to progress,

9 As mentioned before, such an effect of a suddenly disruptive stomp gesture here is unique to Debussy's roll; the crescendo could be interpreted as gradually leading towards it. This could be heard in Michelangeli's recording. Again, this concept of trampling is unique to Debussy's interpretation. 
however, it is not only trampled over, but also deemed irrelevant by an effortless planing of chords a few bars later (bar 50), where chords can glide up and down without any work. Thus, in section $\mathrm{D}$, any effort for upward progression is crushed and deemed unnecessary. This coincides with the incoherent, circular juxtaposition of gestures of the disorientation process (Figure 4, colour blocking), and is the height of the disorganization in both processes before the climax.

\section{Climax: Brief Coherence Undercut by Confusion}

The final stage of the two processes is at the Expressif section (musical example 1, 1 '08'). The pivotal, unstable $\mathrm{D}$ in bars 58 to 63 gives way to a fleshing out and extension of the upward reaching movement, as well as a glimpse of coherence that counterbalances the sense of disorientation up to this point. The short bursts of gestures now become developed: the lunging forward gesture in the beginning is fleshed out below, and extended as an upward-reaching melody (bars 63-66, bracketed in red), and the teeter-totter gesture is augmented and given phrasings that make them into an upward progression of phrases (bars 67-70, boxed in green). Also, the climax is here achieved through an extended harmonic progression that is an elongation of the V-I stomp gesture (bar 73-76, chord progression outlined), in contrast to the previous chromatic limp towards peak 1 (bar 44, Figure 10). Debussy's relatively steady tempo also contributes to the sense of coherence. Instead of short bursts that come and go, the gestures stay and become expressively developed into an upward reach towards the climax.
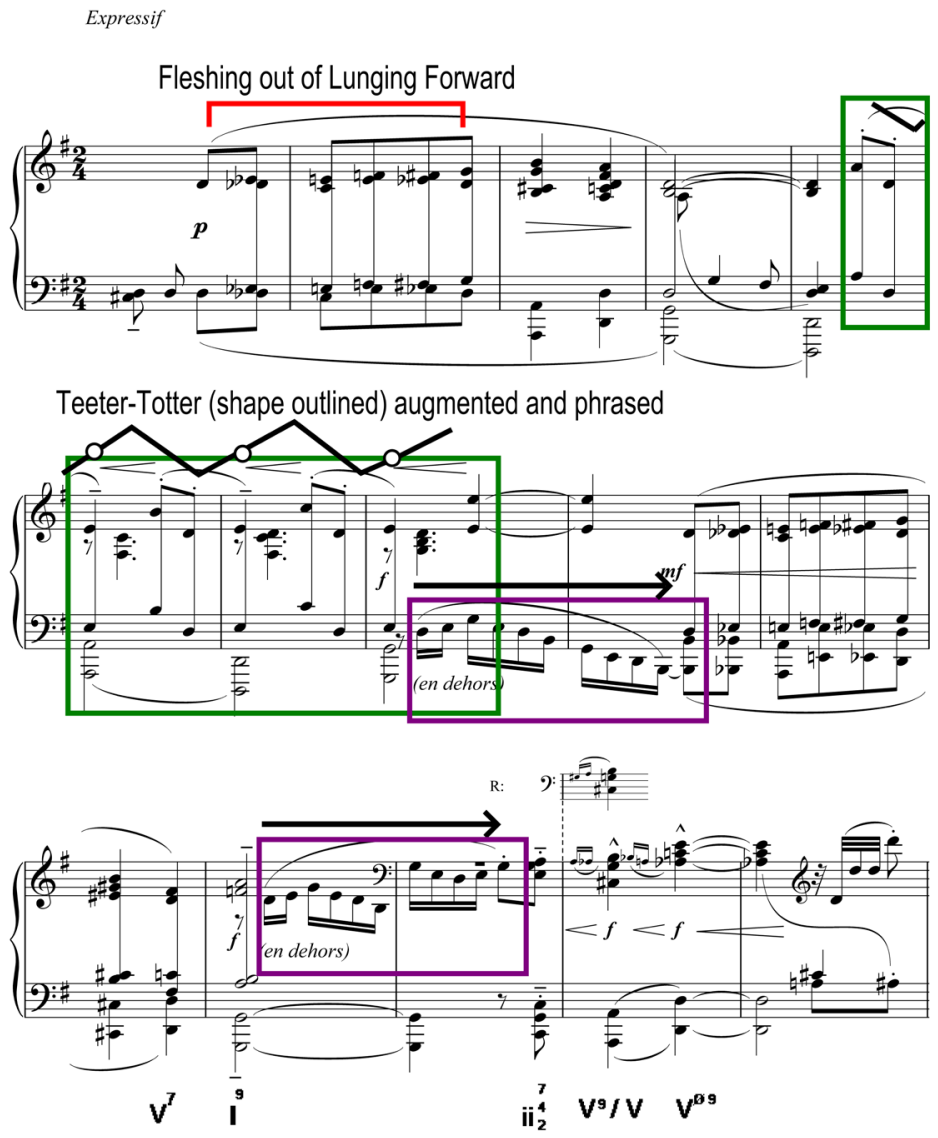

Figure 11: "Minstrels," bars 63-77. 
However, this sense of coherence is undercut by the sudden, incongruous appearances of the tumbling down gesture in bars 70 and 74 (boxed in purple). Debussy plays these gestures abruptly fast, as if the previous sense of disorientation intrudes on the expressive, long lines. Here, we see an obvious instance where performing practices actively contributes to the structure of the piece. While another pianist might interpret the en dehors marking as a subtle dynamic prompt and play the tumbling gesture within the texture of the expressive section, Debussy plays it as an incongruous disruption that mangles the established steady tempo, smooth texture and melodic phrasings. Thus, according to Debussy's performance, the upward movement towards coherence that so satisfyingly counteracts the previous confusion is comically sabotaged by two quick tumbles downwards.

Indeed, the climax - the highest note in the piece - is reached by the appearance of the clumsy crushed chords and the lunge upwards again that was heard in the limping towards peak 1 . The glimpse of coherence is only brief; disorientation and destabilization does not stay away for long. In fact, the sense of disorientation is achieved both in time and in space. While interruptions and incoherent juxtapositions of gestures happen temporally, the incongruity of the tumbling gesture exists within a texture, that is, a sound space. This is represented in Figure 4, where the incongruous purple arrow exists within the texture of the surrounding yellow-orange space. The tumbling-gesture thus becomes a marker of disorientation temporally and spatially: it is the only gesture that appears in its original form in the temporally incoherent section $\mathrm{D}$, as well as the gesture of spatial intrusion in section $\mathrm{E}$. The appearance of this marker of disorientation at the very end of the piece (bars 87-88) emphasizes the overriding comical confusion over coherence; the recycling of original gestures in the return of $\mathrm{A}$ and the coda reinforces non-sensical circularity over the progressive upward reaches. Thus, throughout the piece, the gestures undergo two processes that achieve a brief glimpse of orderly progression, only to be ultimately dominated by a sense of destabilization and giddiness.

\section{Situating the Body in a Socio-Historical Context}

From this analysis of "Minstrels" that integrates Debussy's performance with musical details found in the score, two thematic processes of disorientation and of upward reaching are heard to dictate the overall structure. Debussy's performance of "Minstrels" forefronts the gestural composition of the piece; consequently, transformations of gestures and the nature of structural events such as the peak, the pivotal moment, and the climax are manifested in ways that a traditional score-based analysis alone could not capture. Because of the analogy between the physical gesture of the piece and the bodily acts found in the blackface minstrel show, we can logically ask: what cultural significances of the minstrel show can be read in Debussy's interpretation of "Minstrels," if at all? Historian Eric Lott describes the minstrel show as "one of the very first constitutive discourses of the body in American culture" (Lott 1993, p. 117). From a socio-historical standpoint, the minstrel show was a way in which white people kept black culture under control through the "subjection of black maleness" and of the "black" male body (ibid., p. 115). According to Lott, the 
"black" body was perceived as holding a power that was foreign and dangerous; for instance, Charles Dickens gives a vivid account of Juba, a black dancer in blackface, where he is both dazzled and dismissive at the same time. This threat of the "black" male body is contained through blackface parody, mocking black people's movements and dances.

Indeed, in Debussy's "Minstrel," we hear the body's potential power being inhibited: a hampering of any logical, reasonable progression through disruptions and disorganization, and the emphasis on awkwardness and the non-sensical. Specifically, the trampling and ridiculing of any upward progression in section $\mathrm{D}$ and the dominance of the marker of temporal and spatial confusion - the tumbling down gesture-over any sense of coherence point towards such a cultural reading. In a similar way, Lott notes the suppression of "black" power in the "complete nonsense of some songs" used to "dampen any too boisterous talk" of insurrection, and the "grotesque contortions" of the body as parodying "unsuccessful sublimations of sexual desire" (Lott 1993, p. 117-119).

Moreover, in "Minstrels," we hear something that offers us a sudden, unexpected glimpse of the perceived "dangerous power" of the "black" body: in the abruptly interruptive, structural pivotal moment of the repeated Ds in bars 58 to 62 (Figure 8). The repeated Ds are unexpected in that they suddenly interrupt the previous section, and Debussy's execution of the arbitrary push and pull of tempo without a reference point leaves us dangerously unstable. This pivotal moment could lead to anywhere; while the full body is engaged in this unanchored push and pull in space, there is a momentary recognition of the potential for this unstable body to catapult itself into a different scenario unfettered by the awkwardness, the disarray, the clumsiness. However, just as the "black" "dangerous" body is recognized but contained, suppressed, and parodied, so this brief glimpse of the potentiality for a different bodily comportment deflates to the crassness of a sentimental song that is humorously pleasing and familiar to the minstrel show. It is just as it is in the minstrel show, the blackface performer's body is at once fascinating in its spectacular moves and pleasingly funny. Thus, through the consideration of the body as situated in a historical context, structural processes and gestural tendencies in "Minstrels" take on socio-historical significances that pertain to the threat and the consequent suppression of the "black" body in the minstrelsy show.

\section{CONCLUSION}

The analysis above has used the performative and the alluded minstrel's body as the starting point to explore questions of meaning in Debussy's performance of "Minstrels" in his 1912 piano rolls. By regarding the work as an amalgam of score and performance, the analysis addresses features that are missing from the notation but that contribute vitally to the structure of the music. The shift of focus from analysis that utilizes score alone to include performance casts light on music making and listening as a bodily, rather than merely cognitive, activity. This bodily approach is especially useful in studying historical performing practices such as on Debussy's piano rolls. While piano playing from the turn of the century as evidenced 
on these recordings may sound strange and full of unfamiliar expressive techniques to the modern-day ear, it is worth investigating, together with the written notation, the bodily comportments of the performer (and the listener) and the significances they may hold.

A gestural analysis that understands gesture as both musical and physical phenomena is fruitful in this kind of integrative analysis. In "Minstrels," the physical gesture is also linked to the bodily acts in the blackface minstrel show; a closer historical reading of the body shows that the structure of the piece as revealed by the analysis affords cultural meanings. The convergence between the study of historical performing practices and embodied gestural analysis thus yields fresh, important insights into the structure, inner workings and cultural significances of Debussy's music.

\section{BIBLIOGRAPHY}

Blair, John G. (1996), "Blackface Minstrels and Buffalo Bill's Wild West. Nineteenth-Century Entertainment Forms as Cultural Exports," in John Dean and Jean-Paul Gabilliet (ed.), European Readings of American Popular Culture, Westport/London, Greenwood, p. 3-12.

Cockrell, Dale (2013), "Blackface Minstrelsy," http://www.pbs.org/wgbh/amex/foster/sfeature/ sf minstrelsy 1.html, accessed 29 September, 2013.

Cook, Nicholas (2003), "Music as Performance," in Martin Clayton, Trevor Herbert and Richard Middleton (ed.), The Cultural Study of Music. A Critical Introduction, New York/London, Routledge, p. 204-214.

Cox, Arnie (1993), "Hearing, Feeling, Grasping Gestures," in Anthony Gritten and Elaine King, Music and Gesture, Aldershot, Ashgate, p. 45-60.

Debussy, Claude (c1985), Euvres complètes de Claude Debussy. Série I (Euvres pour piano), "Vol. 5. Préludes," ed. by Roy Howat and Claude Helffer, Paris, Durand-Costallat.

Debussy, Claude (1985-2002), Euvres complètes de Claude Debussy. Série I (Euvres pour piano). ed. by Roy Howat, Paris, Durand-Costallat.

Hitchcock, H. Wiley, and Pauline Norton (2009), "Cakewalk," Grove Music Online, http://www. oxfordmusiconline.com/subscriber/article/grove/music/04568, accessed 24 June, 2009.

Lidov, David (1987), "Mind and Body in Music," Semiotica, vol. 66, nº 1, p. 70-97.

Lott, Eric (1993), Love and Theft. Blackface Minstrelsy and the American Working Class, New York/ Oxford, Oxford University Press.

Fisher, George, and Judith Lochhead (2002), "Analyzing from the Body," Theory and Practice, vol. 27, p. 37-68.

McKinley, Ann (1986), "Debussy and American Minstrelsy," The Black Perspective in Music, vol. 14, $\mathrm{n}^{\circ}$ 3, p. 249-258.

Merleau-Ponty, Maurice (1999), "The Phenomenology of Perception," in Donn Welton (ed.), The Body. Classic and Contemporary Readings, Malden/Oxford, Blackwell Publishers, p. 150-177.

Merleau-Ponty, Maurice ([1962]1978), The Phenomenology of Perception, translated by Colin Smith, London, Routledge \& Kegan Paul.

Nathan, Hans (1977), Dan Emmett and the Rise of Early Negro Minstrelsy, Norman, University of Oklahoma Press.

Schmitz, E. Robert (1950), The Piano Works of Claude Debussy, Canada, Duell, Sloan \& Pearce. 
Smith, Richard Langham (1999), "Debussy on Performance. Sound and Unsound Ideals," in James R. Briscoe, Debussy in Performance, New Haven, CT, Yale University Press, p. 3-27.

Timbrell, Charles (2003), "Debussy in Performance," in Simon Trezise (ed.), The Cambridge Companion to Debussy, Cambridge/New York, Cambridge University Press, p. 239-277.

\section{DISCOGRAPHY}

Debussy, Claude (1912), Children's Corner Suite, Claude Debussy, Welte-Mignon Piano Roll 2733.

Debussy, Claude (1912), D'un cahier d'esquisses, Claude Debussy, Welte-Mignon Piano Roll 2734.

Debussy, Claude (1912), "La cathédrale engloutie," Claude Debussy. Welte-Mignon Piano Roll 2738.

Debussy, Claude (1912), "La danse de Puck," Claude Debussy, Welte-Mignon Piano Roll 2738.

Debussy, Claude (1912), La plus que lente (Valse), Claude Debussy, Welte-Mignon Piano Roll 2736.

Debussy, Claude (1912), "La soirée dans Grenade," Claude Debussy, Welte-Mignon Piano Roll 2735.

Debussy, Claude (1912), "Le vent dans la plaine," Claude Debussy, Welte-Mignon Piano Roll 2739.

Debussy, Claude (1984), Préludes Volume 1, Arturo Michelangeli, Deustche Grammaphon B000001G56, CD.

Debussy, Claude (1999), Préludes, Book I, n 12 “Minstrels," Arthur Rubinstein, RCA Red Seal \#63030, CD.

Debussy, Claude (2012), "Minstrels," Claude Debussy, Welte-Mignon Piano Roll 2739 (rec. 1912), transfer by Denis Hall. 